\title{
THE ROLE OF MIGRATION AS ADJUSTMENT MECHANISM IN THE CRISIS AND EMU
}

\author{
Peter Huber ${ }^{1}$ \\ ${ }^{1}$ Austrian Institute of Economic Research (WIFO) and Ekonomikos Fakultetas, Vilniaus Universitetas, Arsenal, \\ Objekt 20, 1030 Wien, Austria
}

To cite this article: HUBER PETER. 2018. The Role of Migration as Adjustment Mechanism in the Crisis and EMU. Acta Universitatis Agriculturae et Silviculturae Mendelianae Brunensis, 66(6): 1497-1508.

To link to this article: https://doi.org/10.11118/actaun201866061497

\begin{abstract}
Using ELFS data from 2004 to 2014 we analyse labour migration as an adjustment mechanism to asymmetric regional labour demand shocks shortly before, during and after the Great Recession in the EU. The results suggest that in this period migration was rather responsive to regional economic conditions, but also point to a substantial heterogeneity across demographic groups, periods and country groups. The mobility of high-skilled persons and foreign born contributed much more strongly to the adjustment of labour markets than the migration of less-skilled and natives. Furthermore, among the large integration steps from 2004 to 2014 (i.e., the accession of 12 countries to the EU and the successive liberalisation of immigration from the countries joining the EU after 2004 and Euro accession) mainly the EU-enlargements worked to improve the adjustment capability of European labour markets through migration.
\end{abstract}

Keywords: labour market adjustment, migration, EU-enlargement

\section{INTRODUCTION}

Much of the public debate suggests that immigration is a cause rather than a solution of economic and social problems. Economists, however, have a much more favourable view of migrants. According to them, migration is an important adjustment mechanism to regional disparities: As migrants move from places with low returns to their specific human capital to places with higher returns, they - aside from increasing their individual income - contribute to equilibrating regional and national labour markets and equalize living conditions across countries and regions. Therefore, a large body of economic literature considers lacking labour mobility to be an impediment to economic growth, a cause for high and persistent regional labour market disparities and a major factor hampering the improvement of living conditions both in the EU and in other regions of the world (e.g Quispe-Agnoli and Zavodny, 2002;
Lall et al., 2006; Janiak and Wasmer, 2008; Mas et al., 2008 and Huber and Tondl, 2011).

On the one hand this is because mobility is a possibility for individuals (and/or households) to improve their well-being and to escape from unemployment and poverty. On the other hand, this is because countries with low labour mobility are unlikely to take full advantage of the positive effects of urbanization on productivity and income growth in the long run (see World Bank, 2009) and because in low labour mobility environments adverse region-specific shocks to labour demand lead to large and persistent regional disparities in terms of income and unemployment. This last point is of particular importance in the context of monetary unions, such as the European Monetary Union (EMU), because ever since the seminal contribution of Mundel (1961) it is clear that monetary unions inter alia require sufficient labour market flexibility (either in the form of wage adjustments or mobility) to be viable. 
The current paper analyses the efficacy of migration as an adjustment mechanism during the Great Recession in the EU by extending a recent empirical investigation of Caneda and Kovak (2016) on the US to the EU. Using European Labour Force Survey (ELFS) data from 2004 to 2014 we ask how the importance of internal and cross-border migration in the EU as an adjustment mechanism to asymmetric shocks has evolved before, during and after the Great Recession and whether Euro adoption or EU enlargement have affected labour market adjustment in the EU. The paper, therefore, augments existing evidence on the role of internal and cross-border migration as a labour market adjustment mechanism in the EU. It also extends on exiting literature by asking how Euro adoption and EU-enlargements have impacted on migration as an adjustment mechanism to asymmetric shocks in labour demand. The next section of the paper provides a survey of the literature, while the sections three and four discus the method and data, respectively. Section five, presents results, and section six finally concludes.

\section{Literature Survey}

The starting point of the current analysis is the rather large literature on the contribution of migration to adjusting asymmetric labour demand shocks in the EU. A first wave of this research was motivated by the ongoing debate on the viability of EMU in the 1990's. One strand of this literature builds on a much-cited contribution by Blanchard and Katz (1992), which uses data on US states from 1978 to 1991 to run tri-variate vector autoregressions of the log of employment, the employment rate (i.e. one minus the unemployment rate) and participation rate to assess the contribution of migration to accommodating exogenous shocks to regional labour demand. This approach was subsequently applied to other countries in and outside the EU (see Decressinand and Fatas, 1995; L'Angevin, 2007). In general, these studies find that migration contributes less to the adjustment to labour market shocks and that changes in activity rates are a more important adjustment mechanism in the EU than in the US (see Tab. I). Although some authors (Fredrickson, 1998; Deglaigle and Lohest, 1999; Bentolila and Jimeno, 1998) find a larger role for adjustment through migration for some EU countries (Sweden, Belgium and Spain), these results were also further corroborated in many country studies (e.g. Boersma and van Dijk, 2002; Pekkala and Kangasharju, 2000), and for the 12 countries that joined the EU after 2004 (Gacs and Huber, 2005).

The financial and economic crisis (and the formation of the EMU) has recently raised renewed interest in this strand of research. This second wave of research shows an increased responsiveness of migration to asymmetric labour demand shocks, which, however, is still weaker than in the US. For instance, Dao et al. (2014) assess the adjustment of US states for the period 1978 to 2013 and NUTS 1 EU regions for the period 1998 to 2009. Consistent with recent evidence of a long-term downward migration trend (Molloy et al., 2011) they find that in the US the role of participation and unemployment as an adjustment mechanism has increased, while the contribution of inter-state mobility has decreased. In European regions, by contrast, the short-term response of labour mobility has increased over time. In a similar vein Beyer and Smets (2014) compare US and EU labour market adjustments to find a larger role for migration than the research predating economic crisis and EMU formation. Finally, Arpaia et al. (2014) find that the importance of mobility in adjusting regional shocks has increased since the financial and economic crisis.

While the Blanchard and Katz (1992) approach generates important insights, there are also some limitations. The first is that it imputes migration from the response of the participation and the employment rate to aggregate employment fluctuations. Ideally, to assess the responsiveness of migration to changes in labour demand, however, one would like to focus on a more direct measure of migration or population growth. The second is that, since identification of the parameters of the model relies on time variation within regions, it requires long time series and thus does not lend itself to analysing the potential changes in the responsiveness of migration to labour demand shocks found in the previous literature. Finally, the approach also does not lend itself to analysing the potential differences in mobility reaction to labour demand changes of different population groups (such as persons of different qualification levels, different nationalities or between genders).

As a consequence, a second much followed approach has been to estimate single equation models of a measure of migration or population change (as a proxy for mobility) in a region to changes in aggregate labour demand (such as employment growth, the unemployment rate or GDP growth) and a set of further control variables deemed to be important for migration decisions. Borjas (2001) uses this approach to analyse the impact of immigrants on regional labour market adjustment. He argues that migrants as a rule are more responsive to asynchronous changes in labour demand across regions, as they have already paid for some of the migration costs (such as for instance the costs of leaving behind friends and family). He finds that in the US immigrants "grease the wheels" of the economy and presents evidence that labour market segments which experienced more immigration showed clearer tendencies of regional convergence than ones which experienced below average immigration.

As with Blanchard-Katz (1992) also this analysis has been repeated for many European countries and has recently also been applied to EU-wide data. Most of this evidence suggests higher mobility among 
I: Shares of Shock Accommodated by alternative Adjustment mechanisms according to previous Literature

\begin{tabular}{|c|c|c|c|}
\hline & Employment Rate & Participation Rate & Net Migration \\
\hline $\begin{array}{l}\text { US (1978-1990, } 51 \text { States) } \\
\text { Blachard and Katz (1992) }\end{array}$ & 34 & 26 & 40 \\
\hline $\begin{array}{l}\text { Europe (12 member States, 1973-2005) } \\
\text { L'Angevin (2007a,b) }\end{array}$ & 33 & 44 & 23 \\
\hline $\begin{array}{l}\text { Europe (1975-1987, } 51 \text { Regions) } \\
\text { Decressin and Fatas (1995) }\end{array}$ & 22 & 75 & 4 \\
\hline $\begin{array}{l}\text { Spain* (1976-1994, } 17 \text { regions) } \\
\text { Bentolila and Jimeno (1998) }\end{array}$ & 36 & 23 & 41 \\
\hline $\begin{array}{l}\text { Sweden (1966-1993, } 24 \text { regions) } \\
\text { Fredrickson (1998) }\end{array}$ & 8 & 26 & 66 \\
\hline $\begin{array}{l}\text { Finland (1976-2000, } 11 \text { regions) } \\
\text { Pekkala and Kangashartju (2002) }\end{array}$ & 27 & 65 & 8 \\
\hline $\begin{array}{l}\text { Netherlands* (1993-1999, } 18 \text { regions)** } \\
\text { Boersma and van Dijk (2002) }\end{array}$ & 14 & 74 & 12 \\
\hline $\begin{array}{l}\text { Belgium (1970-1995, } 3 \text { Regions })^{\text {a) }} \\
\text { Deglaigle and Lohest (1999) }\end{array}$ & -4 to 22 & 3 to 33 & 45 to 99 \\
\hline $\begin{array}{l}\text { Germany ( } 8 \text { regions, } 27 \text { years) } \\
\text { Fatas }(2000)\end{array}$ & 12 & 93 & -5 \\
\hline $\begin{array}{l}\text { Italy (11 regions, } 27 \text { years) } \\
\text { Fatas }(2000)\end{array}$ & 37 & 62 & 1 \\
\hline $\begin{array}{l}\text { UK (11 regions, } 27 \text { years) } \\
\text { Fatas }(2000)\end{array}$ & 12 & 91 & -3 \\
\hline $\begin{array}{l}\text { ES, DE, PT, IT, NL(1989-1995, } 68 \text { Regions) } \\
\text { Gacs and Huber (2005) }\end{array}$ & 34 & 68 & -2 \\
\hline $\begin{array}{l}\text { First Round new EU countries (1992-1998, } 141 \text { regions) } \\
\text { Gacs and Huber ( } 2005 \text { ) }\end{array}$ & 19 & 75 & 6 \\
\hline \multirow[t]{2}{*}{$\begin{array}{l}\text { Second Round new EU countries (1992-1998, } 69 \text { regions) } \\
\text { Gacs and Huber ( } 2005 \text { ) }\end{array}$} & 90 & 62 & -53 \\
\hline & \multicolumn{3}{|c|}{ Recent Results } \\
\hline $\begin{array}{l}\text { US ( } 51 \text { US States, } \\
\text { Dao et al. (2014) }\end{array}$ & 22 & 24 & 54 \\
\hline $\begin{array}{l}\text { EU (173 NUTS I regions, 1998-2009) } \\
\text { Dao et al. (2014) }\end{array}$ & 16 & 60 & 24 \\
\hline $\begin{array}{l}\text { EU ( } 47 \text { regions, } 1977-2011) \\
\text { Beyer and Smets }(2014)\end{array}$ & 30 & 40 & 31 \\
\hline $\begin{array}{l}\text { EU ( } 15 \text { countries } 1970-2013)^{*} \\
\text { Arpaia et al (2014) }\end{array}$ & 43 & 32 & 25 \\
\hline $\begin{array}{l}\text { EU (15 countries 1970-2007)* } \\
\text { Arpaia et al. }(2014)\end{array}$ & 34 & 38 & 28 \\
\hline
\end{tabular}

Source: Gacs and Huber (2005), Arpaia et al (2014) * Quarterly Data, ** First quarter a) separate for each of three regions.

immigrants than among natives and therefore favours the "greasing the wheels" hypothesis. For instance, Anauedo-Dorantes and de la Rica (2005) show that immigrants are more responsive to regional employment differentials than natives in their migration decision, Schündeln (2007) finds the same for Germany as do Roed and Schone (2010) for the entry, exit and within country mobility decisions of immigrants in Norway and Aslund (2001) in for Sweden. More recently Jauer et al. (2014) used this approach to show that, somewhat in contrast to the results of the pre-crisis literature, the migration response to the Great Recession has been considerable in the EU and much less substantial in the US. According to their results, in an upper bound estimate, migration absorbed a quarter of an asymmetric labour demand shock within a year, during the crisis years in the EU.

\section{MATERIALS AND METHODS}

\section{Method}

In a recent study, Cadena and Novak (2016) use a similar approach in which they regress regional population changes on measures of regional employment growth in the US to find that low skilled Mexican-born immigrants responded much more strongly to local labour demand shocks than low skilled natives. This also led to a reduced impact of local demand shocks on natives, in regions with a high share of Mexican born residents. For 
a given labour demand shock natives living in metro-areas with a substantial Mexican-born population experienced a $50 \%$ weaker reduction in employment than in metro-areas with only few Mexican immigrants living in that area.

In the current paper we adapt Cadena and Novak's (2016) analysis to the EU. This means that we run regressions which link the logarithm of population growth $\left(\dot{N}_{i t}\right)$ it in region i and year to the $(\log )$ employment growth $\left(\dot{L}_{i t}\right)$ as a measure of the labour market shock, such that:

$\dot{N}_{i t}=\delta \dot{L}_{i t}+\gamma_{i}+\xi_{i t}$

In this regression the region fixed effect $\left(\gamma_{i}\right)$ controls for any region specific long-term trends in population growth (such as for instance the long-term population decline due to ageing of the population that would affect several European regions in the absence of immigration). $\delta$ by contrast measures the contemporaneous impact of a 1 percentage point increase in employment growth on regional population growth (in percentage points). ${ }^{1}$

The most important issue related to the estimation of equation ( 1 ) is the potential endogeneity of the measure of the change in labour demand. This may for instance arise if changes in mobility are driven by other determinants of the location choice of migrants and natives that simultaneously also affect employment growth. The inclusion of region fixed effects is likely to substantially reduce this missing variable bias in the short time series we analyse. Furthermore this issue is likely to be of lesser relevance for the analysis of the immediate crisis period as, due to the rapid decline of demand in this period, changes in labour supply (and wage adjustments) are likely to have had only a minor effect on relative employment performance. Nonetheless, we also conduct an IV-analysis in which we use a Bartik (1991) type measure as an instrument for changes in regional employment, to account for this potential endogeneity. This instrument, which has also been used by Caneda and Nowak (2016), predicts a region's employment change by applying its occupational structure in the initial period to the national employment changes in the respective occupation.

In the analysis below we will thus estimate both an OLS and an IV version of equation (1) for overall regional population growth as well as for separate country groups (the EU15, the EU13 and non-EU countries) ${ }^{2}$, different time periods (the pre-crisis period, the crisis period and the post-crisis period) and for different population groups (delineated by gender, age, education and migrant status), where in the last of these exercises we use employment and population growth of the respective group to estimate equation (1).

Furthermore, we also use this basic set-up to assess the impact of EU-enlargement and Euro-adoption on migration as a labour market adjustment mechanism in the EU. To do this, we extend Cadena and Novak's (2016) approach by focusing on status changes with respect to EU membership, Euro adoption and freedom of movement in a difference in difference like set-up. To achieve this we define a set of four different dummy variables that take on a value of one if a country joined the EU, if a country joined the Eurozone or if a country granted freedom of movement to the EU countries of the 2004 or the 2007 enlargements in the period of analysis considered here, respectively, and interact this with a dummy which is equal to one in the time after which this status change occurred. In this step of the analysis therefore the relevant regression is:

$$
\begin{aligned}
& \dot{N}_{i t} \aleph{ }_{3} D^{F M 04}{ }_{4} D^{F M 07}{ }_{1} D^{E U} \dot{L}_{i t} \\
& +\delta_{2} D^{E M U} \dot{L}_{i t}+\delta_{3} D^{F M 04} \dot{L}_{i t}+\delta_{2} D^{F M 07} \dot{L}_{i t}+\gamma_{i}+\tau_{t} \dot{L}_{i t}+\xi_{i t}
\end{aligned}
$$

where $D^{E U}$ is the dummy variable for a country joining the EU which takes on the value of 1 for Bulgarian and Romanian regions in the period after 2007. $D^{E M U}$, by contrast, is the dummy variable for joining the Eurozone. This takes on the values of one for, for Slovene regions after 2006, Malta and Cyprus after 2007, for Slovak regions after 2008 and for Estonia and Latvia after 2010 and 2013 respectively. Similarly, $D^{F M 04}$ and $D^{F M 07}$ are dummy variables signalling freedom of movement after the 2004 enlargement and after the 2007 enlargement respectively. $D^{F M 04}$ takes on the value of 1 for Greece, Spain, Finland, Italy, Portugal and Slovenia after 2005, for Poland, the Netherlands and Luxemburg after 2006, France after 2007, Belgium, Denmark and Hungary after 2008 and Austria and Germany after 2010. D ${ }^{F M 07}$ is 1 for Finland, Sweden, and all EU13 countries except for Malta after 2007, for Italy and Ireland after 2007 and for Austria, Germany, France, Belgium, the Netherlands, Luxemburg, the UK and Malta after 2013. The central parameters in this regression are the coefficients $\delta_{1}, \delta_{2}, \delta_{3}$ and $\delta_{4}$. These indicate by how much the responsiveness of labour migration to labour demand shocks changed after EU-enlargement, Euro-adoption or the granting of freedom of movement of labour after the enlargements of 2004 and 2007, respectively.

1 This is because $\dot{N}=\log \left(N_{i t} / N_{i t-1}\right) \approx g_{i t}^{N}$ and $\dot{L}=\log \left(L_{i t} / L_{i t-1}\right) \approx g_{i t}^{L}$ with $N_{i t}$ the population, $L_{i t}$ the employment and $g_{i t}^{N}$ and $g_{i t}^{L}$ the employment and population growth in a region

2 We refer to the EU15 countries as those countries that joined the EU before 2004, the EU13 countries are the countries that joined the EU since 2004. 


\section{Data}

The main data source for this analysis is the European Labour Force Survey (ELFS). This is used to construct time series on changes in the active aged population (aged 20 to 64) that is not in full time training and does not reside in group quarters ${ }^{3}$ and to obtain information on employment growth. The ELFS covers all 28 EU countries for the period 2005 to 2014 except for Malta (where data are available only as of 2010) and Croatia and Denmark (where data are available as of 2009), as well as Switzerland, Iceland and Norway. For these countries (except for Iceland and the Netherlands - where we use national data) the data include regional information on the NUTS 1 or NUTS 2 level of the respective countries, although in a number of countries only one such region exists. In total the data provide information on 218 regional units for most years. The available sample thus provides a sufficiently large country and time coverage to allow for an analysis by different country types (such as EU15, EU13 and non-EU countries) and different time periods (such as a pre-crisis period from 2005 to 2008, a crisis period from 2008 to 2011 and a post-crisis period from 2011 to 2014$)^{4}$ as well as for a differentiated analysis of different demographic groups.

Fig. 1 reports regional employment growth in the ELFS for four sub-periods (the pre-crisis period from 2004 to 2008, the immediate crisis year 2008 to 2009 , the immediate post-crisis period from 2009 to 2011 as well as the period from 2012 to 2014). It highlights the substantial heterogeneity and asymmetry in terms of the timing of the effect of the financial and economic crisis of 2008/09 on regional European labour market developments. For instance, even in the economic boom period from 2004 to 2008, in which aggregate employment grew by $2.3 \%$ annually in the economies for which we have data, 23 regions (mostly located in Hungary but also including Latvia and some

1: Average annual employment growth rates of the active aged population not in full time training by NUTS2 regions and periods (in \%)

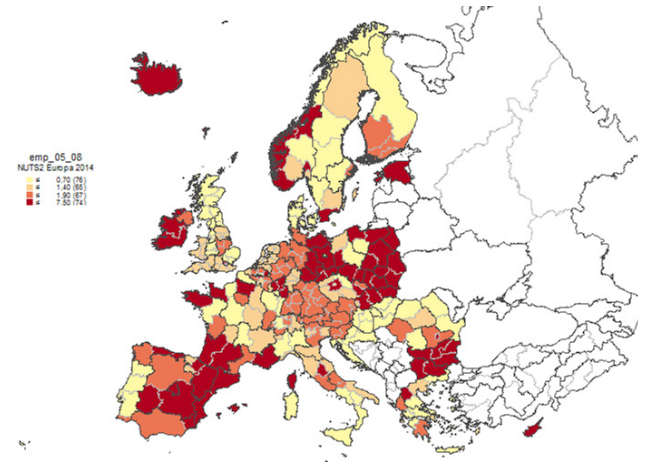

2004-2008

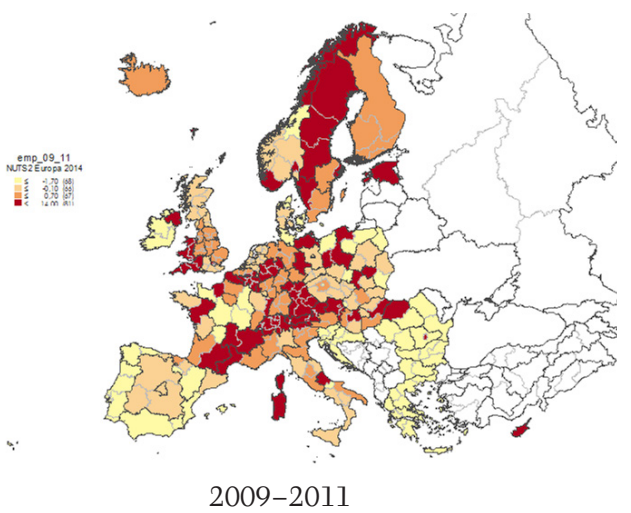

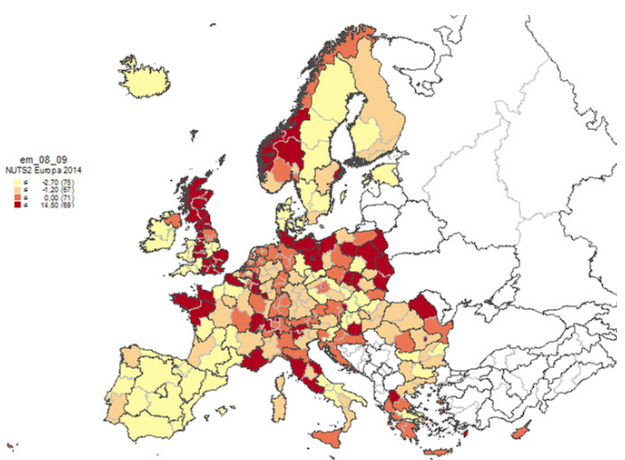

2008-2009

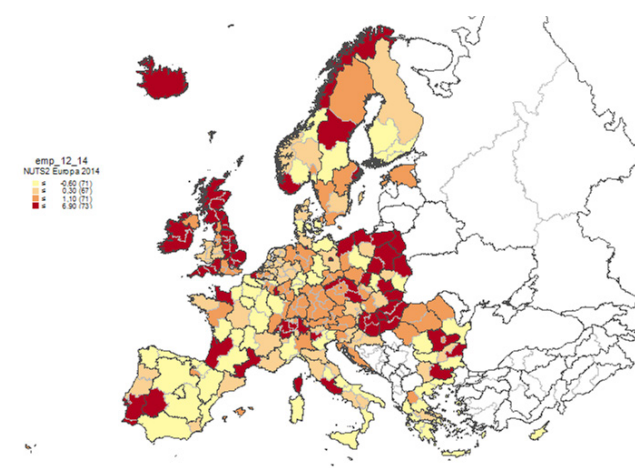

$2011-2014$

S: ELFS, own calculations. Sample: Active aged population (aged 20 to 64) that is not in full time training and does not reside in group quarters

3 These restrictions are set following Caneda and Kovak (2016) as they focus only on that part of the population, whose mobility decisions are most likely to be influenced by economic considerations.

4 This periodisation aims to strike a balance between accurately capturing the period of crisis and subsequent recovery and providing sufficient time variation for a meaningful econometric analysis. 
Spanish and Italian regions) registered declining employment. Thus, the maximum average annual employment growth rate among the European regions in this period amounted to $7.4 \%$ in the Polish Mazowieckie region and the maximum average annual decline in employment was $-2.3 \%$ in the Del-Dunatul in Hungary. In part these highly asymmetric developments reflect asymmetries in economic developments at the national level. For instance, the poor performance of the Hungarian and Latvian labour market can be explained by the financial crises in Latvia and Hungary in 2008 and 2007 respectively. The large heterogeneity of regional labour market developments also applies to the immediate crisis period as well as the two post-crisis periods. Even in the year 2009, when in aggregate around $15 \%$ of the jobs were lost in the EU-economy according to the ELFS, positive employment growth was experienced in around a quarter (58 of 212) of the regions covered.

Similarly, the figure illustrates the different timing and persistence of the effects of the crisis in different parts of the EU. While most of the regions located in the European core countries experienced employment growth in the years after 2009, in many regions located in Southern Europe (Greece, Spain, Portugal and after 2011 also Italy) and Ireland employment declined. This reflects the differences in economic development of the northern and southern European countries since 2009. It, however, also accords with the findings of the literature. This often finds that regions with a high industrial employment share and high employment density as well as a high share of high-tech industries have been more resilient to the economic crisis than regions with low urbanisation, low industrial employment shares and less technology intensive industries (see e.g. Fingleton et al., 2012; Crescenzi et al., 2015; Brakman et al., 2016; Fratesi and Rodriguez-Pose, 2016).

These substantial shifts in relative employment growth rates in the post-crisis period were also associated with shifts in population growth across the European regions (shown in Fig. 2). In part these were associated with the substantial institutional changes in the governance of inter-EU migration that marked the first decade of the 2000's in the Europe, such as the stepwise liberalisation of EU internal migration for citizen of the ten countries that joined the EU in 2004 (between 2004 and 2011) and Bulgaria and Romania (between 2007 and 2014). In part these developments were, however, also triggered by the different economic developments across regions. The correlation

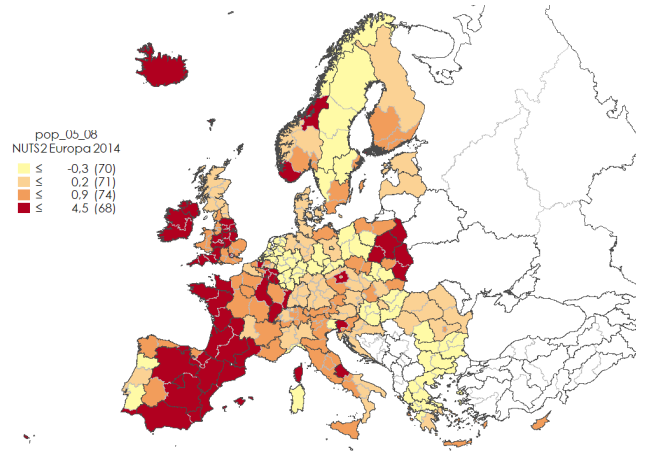

2004-2008

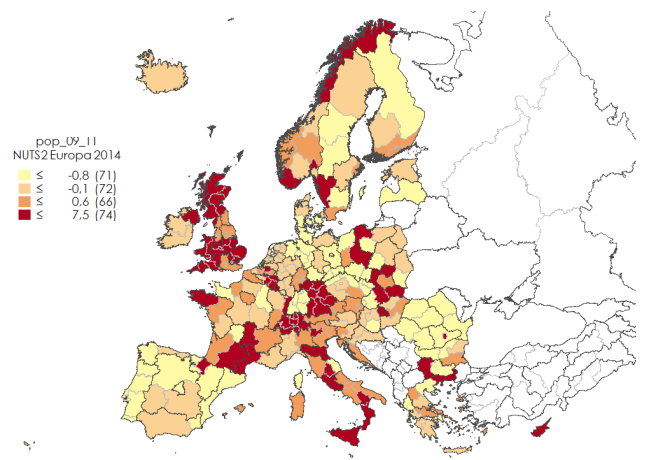

2009-2011

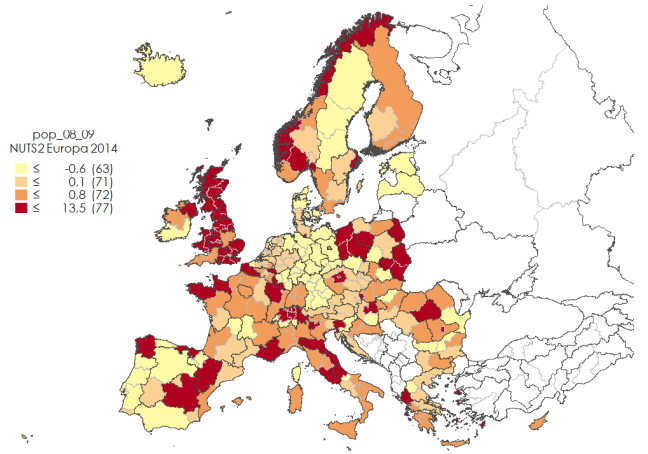

2008-2009

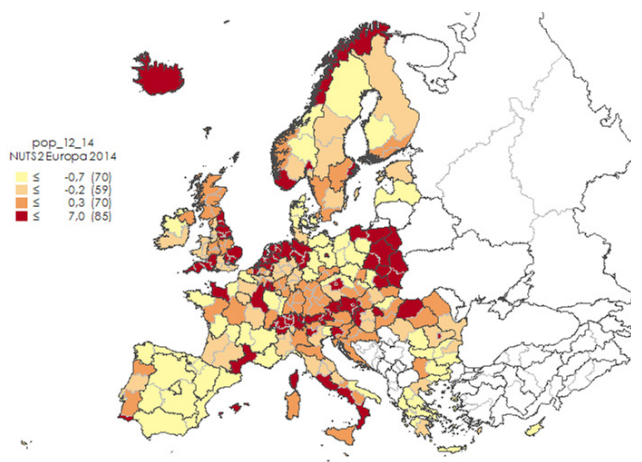

2011-2014

S: ELFS, own calculations. Sample: Active aged population (aged 20 to 64) that is not in full time training and does not reside in group quarters 
between the average annual employment growth and the average annual population growth at the regional level ranges between 0.4 and 0.6 in the four periods considered. Population growth among the active aged population not in full time education was therefore highest in those regions where employment growth was highest. There are, however, also some important exceptions. These apply in particular to the pre-crisis period from 2005 to 2009 , where - in part because of the accession of the EU10 countries - European East-West migration increased substantially. This particularly affected Ireland and large parts of the UK, which received a substantial part of the migrants from the EU10 countries in this period, but also most Spanish regions, which were the main receiving regions of migration from Bulgaria and Romania in that period. Consequently, regional population growth in this period is also highly correlated with the growth of the foreign-born population residing in these regions.

\section{RESULTS}

Descriptive evidence, while highlighting the substantial heterogeneity in regional labour market developments in Europe over the years from 2005 to 2014, therefore suggests that population moves have been an important part of the labour market adjustment in the periods before, during and after the crisis. This is supported by more formal evidence from estimating equation (1) presented in Tab. II, which presents the results of this regressions for the overall sample of regions well as for different country groups (i.e. the EU15, EU13 and non-EU countries). The OLS estimates of this equation (reported in the top panel of Tab. II) imply that a 1 percentage point increase in employment growth increases population growth by 0.36 percentage points. Comparing this to results of Caneda and Kovak (2016), who find a coefficient of between 0.163 and 0.498 for a similar specification for men of different skill groups in US metropolitan areas, suggests a responsiveness of immigration to regional employment growth in Europe that is comparable to that in the US. This responsiveness, however, also varies substantially among the country groups analysed and is highest in regions belonging to non-EU countries, where a percentage point increase in employment is associated with a 0.81 percentage point increase in population growth. By contrast, it is somewhat a smaller in the regions of EU15 and EU13 countries, where this coefficient ranges between 0.32 and 0.39 .

IV-estimates of equation (1) (reported in the bottom panel of Tab. II), however, also suggest that a substantial part of this high coefficient may be due to the endogeneity of the employment growth measure, as IV-estimates are substantially lower than OLS-estimates. Thus, according to these IV-regression, a one percentage point increase in the employment rate over the whole period analysed in an average European region increased population growth by 0.19 percentage points. Furthermore, these results - as the uninstrumented ones - suggest that population growth reacted more strongly to employment growth in non-EU-countries than in either the EU15 or EU13 countries. In contrast to the previous results they, however, also suggest that the reaction in EU15 countries was stronger than in EU13 countries, where the estimated coefficient - after instrumenting - remains insignificant.

\section{Results for different periods and population groups}

The reaction of population growth to labour demand shocks has also varied substantially over different periods and across different population groups. For instance, Tab. III reports the results of estimating equation (1) for each of the three periods considered in this paper (i.e. the pre-crisis, crisis, and post-crisis period). As can be seen the responsiveness of regional population growth to employment changes has been strongest in the period from 2005 to 2008 and has been reduced somewhat

II: Reaction of population growth rates to changes in regional labour demand by country groups

\begin{tabular}{|c|c|c|c|c|}
\hline & All & EU15 & EU13 & non-EU \\
\hline & \multicolumn{4}{|c|}{ OLS } \\
\hline In(employment growth) & $0.358 * * *$ & $0.323 * * *$ & $0.389 * * *$ & $0.805^{* * *}$ \\
\hline Observations & 2093 & 1409 & 554 & 130 \\
\hline \multirow[t]{2}{*}{ R-squared } & 0.31 & 0.272 & 0.386 & 0.696 \\
\hline & \multicolumn{4}{|c|}{ IV } \\
\hline \multirow[t]{2}{*}{ ln(employment growth) } & $0.193 * * *$ & $0.226^{* * *}$ & 0.0385 & $0.654 * * *$ \\
\hline & $(0.052)$ & $(0.069)$ & $(0.051)$ & $(0.118)$ \\
\hline Observations & 2093 & 1409 & 554 & 130 \\
\hline R-squared & 0.31 & 0.272 & 0.386 & 0.696 \\
\hline
\end{tabular}

S: ELFS, own calculations. Sample: Active aged population (aged 20 to 64) that is not in full time training and does not reside in group quarters. Values in brackets are heteroskedasticity robust standard errors, region fixed effect are not reported, R-squared value is overall R-squared, ${ }^{* * *}(* *)(*)$ signify significance at the $1 \%(5 \%)(10 \%)$ level respectively. 
since. Regression coefficients for the instrumented equation are insignificant in the two periods after 2009, but highly significant in the period before 2009. This applies mainly to the EU 15 countries. In the EU13 countries the responsiveness of population growth to employment growth peaked in the period 2009 to 2011.

Similar observations apply to the reaction of different population groups to regional labour demand shocks. This particularly applies to the differences between natives and foreign born as well as to the differences between education groups. All results pertaining to these groups point to a substantially larger reaction of the population growth of the foreign born to regional employment growth than of natives (Tab. IV). A one percentage point increase in the growth of employment of the foreign born increases their population growth

III: Reaction of population growth rates to changes in regional labour demand by country groups and period

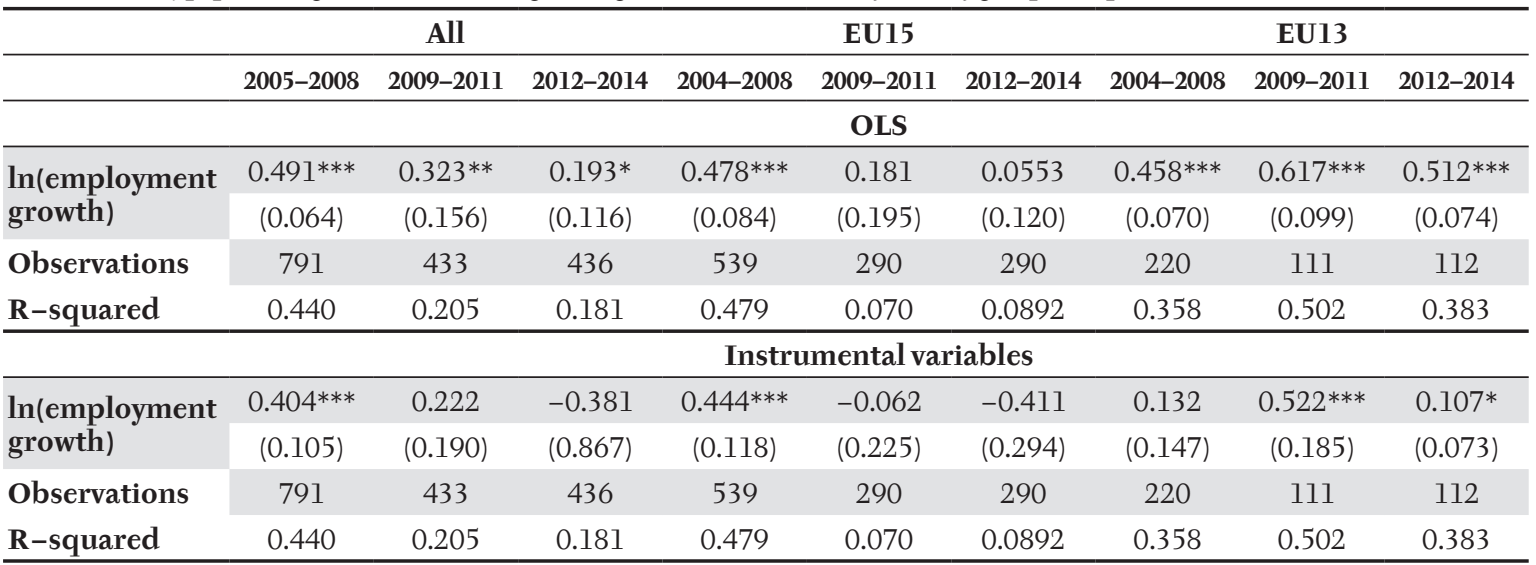

S: ELFS, own calculations. Sample: Active aged population (aged 20 to 64) that is not in full time training and does not reside in group quarters. Values in brackets are heteroskedasticity robust standard errors, region fixed effect are not reported, $\mathrm{R}$-squared value is overall $\mathrm{R}$-squared, ${ }^{* * *}(* *)(*)$ signify significance at the $1 \%(5 \%)(10 \%)$ level respectively.

IV: Reaction of population growth rates to changes in regional labour demand by population groups

\begin{tabular}{|c|c|c|c|c|c|c|c|}
\hline & & Dempl & Obs & Rsq & Dempl & Obs & Rsq \\
\hline & & & OLS & & & IV & \\
\hline \multirow[t]{4}{*}{ Gender } & Males & $0.125^{* * *}$ & 1911 & 0.336 & $0.383^{* * *}$ & 1936 & 0.336 \\
\hline & & $(0.043)$ & & & $(0.057)$ & & \\
\hline & Females & $0.208^{*}$ & 1911 & 0.206 & $0.266^{* * *}$ & 1936 & 0.207 \\
\hline & & $(0.115)$ & & & (0.097) & & \\
\hline \multirow[t]{6}{*}{ Age } & $20-34$ & $0.253^{* * *}$ & 1911 & 0.506 & $0.543^{* * *}$ & 1936 & $(0.506)$ \\
\hline & & $(0.079)$ & & & (0.049) & & \\
\hline & $35-49$ & $0.453 * * *$ & 1911 & 0.662 & $0.641^{* * *}$ & 1936 & 0.663 \\
\hline & & $(0.065)$ & & & $(0.021)$ & & \\
\hline & $50-64$ & $0.477^{* * *}$ & 1911 & 0.429 & $0.466^{* * *}$ & 1936 & 0.43 \\
\hline & & (0.099) & & & $(0.047)$ & & \\
\hline \multirow[t]{6}{*}{ Education } & Low & $0.599 * * *$ & 1911 & 0.559 & $0.557^{* * *}$ & 1936 & 0.561 \\
\hline & & $(0.053)$ & & & (0.038) & & \\
\hline & Medium & $0.874 * * *$ & 1911 & 0.810 & $0.770^{* * *}$ & 1936 & 0.809 \\
\hline & & $(0.024)$ & & & $(0.020)$ & & \\
\hline & High & $0.970 * * *$ & 1911 & 0.900 & $0.895^{* * *}$ & 1936 & $(0.900)$ \\
\hline & & $(0.020)$ & & & (0.019) & & \\
\hline \multirow[t]{4}{*}{ Region birth } & Native & $0.358 * * *$ & 1905 & 0.480 & $0.496^{* * *}$ & 1930 & 0.479 \\
\hline & & $(0.079)$ & & & (0.064) & & \\
\hline & foreign born & $0.445^{* *}$ & 1898 & 0.838 & $0.864 * * *$ & 1923 & 0.838 \\
\hline & & $(0.213)$ & & & $(0.037)$ & & \\
\hline
\end{tabular}

S: ELFS, own calculations. Sample: Active aged population (aged 20 to 64) that is not in full time training and does not reside in group quarters. Values in brackets are heteroskedasticity robust standard errors, region fixed effect are not reported, $\mathrm{R}$-squared value is overall $\mathrm{R}$-squared, ${ }^{* * *}(* *)(*)$ signify significance at the $1 \%(5 \%)(10 \%)$ level respectively. 
V: Reaction of population growth rates to changes in regional labour demand by country groups and region of birth

\begin{tabular}{|c|c|c|c|c|c|c|}
\hline & \multicolumn{2}{|c|}{ All } & \multicolumn{2}{|c|}{ EU15 } & \multicolumn{2}{|c|}{ EU13 } \\
\hline & EU-born & Third country & EU-born & Third country & EU-born & Third country \\
\hline & \multicolumn{6}{|c|}{ OLS } \\
\hline \multirow[t]{2}{*}{ employment growth } & $0.623 * * *$ & $0.711^{* * *}$ & $0.695^{* * *}$ & $0.749 * * *$ & $0.460 * * *$ & $0.655^{* * *}$ \\
\hline & $(0.035)$ & $(0.045)$ & $(0.037)$ & $(0.057)$ & $(0.073)$ & $(0.078)$ \\
\hline \multirow[t]{2}{*}{ Rsq } & 0.574 & 0.633 & 0.673 & 0.649 & 0.386 & 0.594 \\
\hline & \multicolumn{6}{|c|}{ Instrumental Variables } \\
\hline \multirow[t]{2}{*}{ employment growth } & $0.634 * * *$ & $0.778 * * *$ & $0.556^{* * *}$ & $0.743 *$ & $0.795^{* * *}$ & $0.749 * * *$ \\
\hline & $(0.091)$ & $(0.110)$ & $(0.111)$ & $(0.388)$ & $(0.238)$ & $(0.154)$ \\
\hline
\end{tabular}

S: ELFS, own calculations. Sample: Active aged population (aged 20 to 64) that is not in full time training and does not reside in group quarters. Values in brackets are heteroskedasticity robust standard errors, region fixed effect are not reported, R-squared value is overall R-squared, ${ }^{* * *}(* *)(*)$ signify significance at the $1 \%(5 \%)(10 \%)$ level respectively.

VI: The impact of policy changes on the responsiveness to migration

\begin{tabular}{|c|c|c|c|c|}
\hline & \multicolumn{4}{|c|}{ Countries } \\
\hline & All & EU27 & EU15 & EU13 \\
\hline \multirow[t]{2}{*}{ employment growth } & 0.144 & 0.102 & -0.179 & 0.186 \\
\hline & $(0.160)$ & $(0.172)$ & $(0.252)$ & $(0.170)$ \\
\hline \multirow[t]{2}{*}{ joined EU } & $-0.0227^{* * *}$ & $-0.0216^{* * *}$ & & $-0.0280^{* * *}$ \\
\hline & $(0.006)$ & $(0.006)$ & & $(0.007)$ \\
\hline \multirow[t]{2}{*}{ JoinedEU*employment growth } & $0.885^{* * *}$ & $0.854 * * *$ & & $1.091^{* * *}$ \\
\hline & $(0.183)$ & $(0.184)$ & & $(0.237)$ \\
\hline \multirow[t]{2}{*}{ joined EMU } & 0.006 & 0.006 & & 0.001 \\
\hline & $(0.004)$ & (0.004) & & $(0.004)$ \\
\hline \multirow[t]{2}{*}{ Joined EMU* Employment growth } & 0.058 & 0.071 & & -0.079 \\
\hline & (0.108) & $(0.113)$ & & $(0.129)$ \\
\hline \multirow[t]{2}{*}{ Granted freedom of movement in enl. 2004} & 0.001 & 0.002 & 0.002 & -0.003 \\
\hline & $(0.002)$ & $(0.002)$ & $(0.003)$ & (0.004) \\
\hline \multirow[t]{2}{*}{$\begin{array}{l}\text { Granted freedom of movement in enl. } \\
2004 * \text { employment growth }\end{array}$} & $0.076^{*}$ & $0.061^{*}$ & $0.157 *$ & 0.222 \\
\hline & $(0.039)$ & $(0.033)$ & $(0.102)$ & $(0.159)$ \\
\hline \multirow[t]{2}{*}{ Granted freedom of movement in enl. 2007} & $0.00536^{* * *}$ & $0.00621^{* * *}$ & $0.00732 * * *$ & 0.007 \\
\hline & $(0.002)$ & $(0.002)$ & $(0.002)$ & $(0.005)$ \\
\hline \multirow[t]{2}{*}{$\begin{array}{l}\text { Granted freedom of movement in enl. } \\
2007^{*} \text { employment growth }\end{array}$} & -0.176 & -0.160 & 0.040 & -0.249 \\
\hline & $(0.115)$ & $(0.122)$ & $(0.206)$ & $(0.229)$ \\
\hline Obs & 1936 & 1801 & 1290 & 511 \\
\hline Rsq & 0.543 & 0.510 & 0.509 & 0.566 \\
\hline
\end{tabular}

S: ELFS, own calculations. Sample: Active aged population (aged 20 to 64) that is not in full time training and does not reside in group quarters. Values in brackets are heteroskedasticity robust standard errors, region fixed effect are not reported, R-squared value is overall R-squared, ${ }^{* * *}(* *)(*)$ signify significance at the $1 \%(5 \%)(10 \%)$ level respectively.

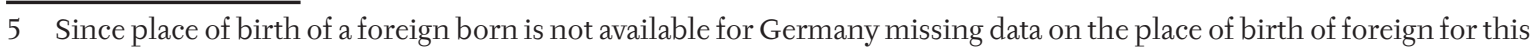
country was imputed from nationality data. 
by between 0.45 and 0.86 percentage points. A $1 \%$ increase in GDP per capita has an impact of around 0.69. For natives the coefficient on employment growth, by contrast, is between 0.36 and 0.50 . Also, the coefficients on employment growth increase with educational attainment in all of the results reported in Tab. IV. A one percentage point increase in the employment growth rate for highly educated in a region leads to a 0.9 to 0.97 percentage point increase in their population growth, while an increase in employment growth of the less educated increases their population growth by only 0.6 to 0.56 percentage points. Differences in the reaction to employment growth between males and females and workers of different age groups, by contrast, are less pronounced and differ between OLS and IV-estimates. The IV-results in Tab. IV suggest a stronger reaction of population growth among males and the middle age groups, while OLS results indicate the strongest responsiveness among the oldest and females.

In addition, dividing the foreign born into those originating from other EU countries and those originating from non-EU countries ${ }^{5}$ (see Tab. IV) suggests that the reaction of foreign born from non-EU countries to regional economic conditions is larger than that of EU-immigrants. Irrespective of whether OLS or IV-results are considered a unit increase in the employment growth of foreign born from non-EU countries has a slightly higher impact on their population growth, than a unit increase of the employment growth EU-immigrants on the population growth of EU-immigrants.

\section{The impact of European integration}

In sum results of estimating equation 1 suggest that migration has been a rather effective adjustment mechanism in the regional labour markets of the EU in the period 2004 to 2014, but that this is mainly due to the migration of highly educated persons and foreign born. The results, however, also point to a substantial variance across the different sub-periods analysed, that also differ between country groups (i.e. between EU13 and EU 15 countries). This suggests that these changes may be related to the major integration steps undertaken in the years from 2004 to 2014 in the EU. In this time period three countries (Bulgaria, Romania - in 2007 - and Croatia - in 2013) joined the European Union and both the citizen of the new member states that joined the European Union in 2004 as well as those that joined in 2007 successively gained free access to the labour markets of the pre-existing
15 EU member states. In addition, a total of six countries (Slovenia in 2007, Cyprus and Malta in 2008, Slovakia in 2009, Estonia in 2011 and Latvia in 2014) joined the European Monetary Union. Each of these steps may have had an impact on the reaction of population growth to regional labour demand in the European labour market. For instance, the accession to the EU, which was associated with freedom of movement of citizens from the joining countries to some of the incumbents (as well as among joining countries) and the subsequent liberalisation of migration to the remaining countries, may have increased the responsiveness of migration to economic conditions in the EU simply because it resulted in a reduction of administrative barriers to migration. Similarly joining the EMU may have increased this responsiveness because of lower transaction costs for migrants across countries of a monetary union.

To test to what degree the changes in the responsiveness of population growth to labour demand are related to these integration steps Tab. 5 reports the results of estimating equation (2). These results indicate that EU accession and the associated freedom of movement for citizen of newly acceding countries were the two most important factors that increased the responsiveness of migration to labour demand in the period from 2004 to 2011. The acceding countries of the 2007 enlargement of the EU - aside from experiencing a decline in their overall population growth by -0.22 percentage points (because of increased emigration) - also experienced a significant increase in the responsiveness of population growth to regional employment growth. Here the statistically highly significant coefficient for the interaction between countries joining the EU in 2007 and employment growth variable that after EU accession the reaction of population growth to a 1 percent increase in employment growth was by 0.885 percentage points higher than before accession.

Similarly, countries that granted freedom of movement to the acceding countries of the 2007 enlargement round experienced a marginally significant increase in the responsiveness of population growth to employment changes of 0.076 percentage points after granting freedom of movement. By contrast, the impact of Euro-adoption as well as granting of freedom of movement to the acceding countries of 2007 has not led to statistically significant increases in the responsiveness of migration to labour demand.

\section{CONCLUSION}

In sum therefore the current paper, finds that migration was rather responsive to regional economic conditions in the period under consideration. These results therefore reflect positively on labour market flexibility in the European Union during the last decade. The more detailed analysis, however, also points to a substantial heterogeneity in the results across demographic groups, time periods, countries and country groups. Thus, the contribution of migration to regional labour market 
adjustment still hinges strongly on a limited number of demographic groups as the mobility of high-skilled persons and foreign-born contributed much more strongly to the adjustment of labour markets than the migration of less-skilled persons and natives. Similarly, the contribution of migration to regional labour market adjustment was also substantially higher in the pre-crisis period (2004 to 2008) than during the crisis (2008 to 2011) or in the post-crisis period (2011 to 2014). The pre-crisis period therefore seems to have been an exceptional period in terms of labour market adjustment in the EU in which the large integration steps from 2004 to 2014 (i.e., the accession of 13 countries to the EU and the successive liberalisation of immigration from the countries joining the EU after 2004) worked to improve the adjustment capability of regional labour markets.

Aside for providing evidence for a link between EU-integration and the efficacy of migration in adjusting regional labour markets in the EU, the current study thus also provides an indication of areas in which the efficiency of migration in adjusting regional imbalances could still be increased. These would primarily be low skilled workers and natives. Future research could therefore focus on determining the specific impediments to migration for these population groups.

\section{Acknowledgements}

This research was funded by the European Social Fund according to the activity 'Improvement of researchers' qualification by implementing world-class R and D projects' of Measure No. 09.3.3-LMT-K-712.

\section{REFERENCES}

AMUEDO-DORANTES, C. and DE LA RICA, S. 2005. Immigrants' Responsiveness to Labour Market Conditions and Its Implications on Regional Disparities: Evidence from Spain. IZA Discussion Papers 1557. Institute for the Study of Labour (IZA).

ARPAIA, A. et al. 2014. European Economy: Labour Mobility and Labour Market Adjustment in the EU. Economic Papers 539. Brussels: European commission.

ASLUND, O. 2005. Now and forever? Initial and subsequent location choices of immigrants. Regional Science and Urban Economics, 35: 141-165.

BARTIK, T. J. 1991. Who Benefits from State and Local Economic Development Policies? Upjohn Press, W.E. Upjohn Institute.

BENTOLILA, S. and JIMENO, J. F. 1998. Regional unemployment persistence Spain, 1976-94. Labour Economics, 5(1): 25-51.

BEYER, R. C. M. and SMETS, F. 2015. Labour market adjustments in Europe and the US: How different? European Central Bank Working Paper Series No. 1767. European Central Bank.

BLANCHARD, O. and KATZ, L. F. 1992. Regional evolutions. Brookings Papers on Economic Activity, 1: 1-75.

BOERSMA, L. and VAN DIJK, J. 2002. Regional Labour Market Dynamics in the Netherlands. Papers in Regional Science, 81(3): 343-364.

BORJAS, G. J. 2001. Does Immigration Grease the Wheels of the Labour Market? Brookings Papers on Economic Activity, 32(1): 69-134.

BRAKMAN, S., GARRETSEN, H., and VAN MARREWIJK, C. 2015. Regional resilience across Europe: on urbanisation and the initial impact of the Great Recession. Cambridge Journal of Regions, Economy and Society, 8(2): 225-240.

CANDEA, B. C. and KOVAK, B. N. 2016. Immigrants Equilibrate Local Labour Markets: Evidence from the Great Recession. American Economic Journal, Applied Economics, 8(1): 257-290.

CRESCENZI, R., DAVIDE, L. and MILIO, S. 2016. The geography of the economic crisis in Europe: national macroeconomic conditions, regional structural factors and short-term economic performance. Cambridge Journal of Regions, Economy and Society, 9(1): 13-32.

DAO, M., FURCERI, D. and LOUNGAMI, P. 2014. Regional Labour market Adjustment in the United States and Europe. IMF Working Paper WP 14/26. International Monetary Fund.

DECRESSIN, J. and FATAS, A. 1995. Regional Labour Market Dynamics in Europe. European Economic Review, 39(9): 1627-1655.

DELAIGLE, S. and LOHEST, O. 1999. Regional Labour Market Dynamics: Evaluation and Application to Belgium. Louvain-la-Neuve: Universite catholique de Louvain.

FATAS, A. 2000. Intranational Labour Migration Business Cycles and Growth. In: HESS, G. D. and VAN WINCOOP, E. Intranational Macroeconomics. Cambridge: Cambridge University Press.

FINGLETON, B., GARRETSEN, H. and MARTIN, R. 2012. Recessionary Shocks and Regional Employment: Evidence on the Resilience of UK Regions. Journal of Regional Science, 52(1): 109-133.

FRATESI, U. and RODRÍGUEZ-POSE, A. 2016. The crisis and regional employment in Europe: what role for sheltered economies? Cambridge Journal of Regions, Economy and Society, 9(1): 33-57.

FREDRIKSON, P. 1998. The Dynamics of Regional Labour Markets and Active Labour Market Policy: Swedish Evidence. Manuscript. University of Upsala. 
GACS, V. and HUBER, P. 2005. Quantity Adjustments in the Regional Labour Markets of EU Candidate Countries. Papers in Regional Science, 84(4): 542-558.

HUBER, P. and TONDL, G. 2012. Migration and Regional Convergence in the European Union. Empirica, 39(4): 439-460.

JANIAK, A. and WASMER, E. 2008. European Economy: Mobility in Europe Why it is low, the bottlenecks and policy solutions. Economic Papers 340. Brussels: European Commission DG-Economic and Financial Affairs.

JAUER, J., LIEBIG, T., MARTIN, J. P., and PUHANI, P. 2014. Migration as an Adjustment Mechanism in the Crisis? A Comparison of Europe and the United States. OECD Social, Employment and Migration Working Papers 155. OECD.

L'ANGEVIN, C. 2007. Labour Market Dynamics and Labour Mobility within the Euro Area. Documents de Travail de la DGTPE 2007/06. DGTPE.

LALL, S. V., SELOD, H. and ZMARAK, S. 2006. Rural-urban migration in developing countries: a survey of theoretical predictions and empirical findings. Policy Research Working Paper Series 3915. The World Bank.

MAS, M., KANGASNIEMI, M., SERRANO, L. and ROBINSON, C. 2008. The Economic Impact of Migration - Productivity Analysis for Spain and the UK. EUKLEMS Working Paper 30.

MOLLOY, R., SMITH, C. L. and WOZNIAK, A. 2011. Internal Migration in the United States. Journal of Economic Perspectives, 25(3): 173-96.

QUISPE-AGNOLI, M. and ZAVODNY, M. 2002. The effect of immigration on output mix, capital,and productivity, Economic Review, Federal Reserve Bank of Atlanta, Q1, 17-27.

PEKKALA, S. and KANGASHARJU, A. 2002. Regional Labour Markets in Finland: Adjustment to total versus region specific shocks. Papers in Regional Science, 81(3): 329-342.

RØED, M. and SCHØNE, P. 2007. Does immigration increase labour market flexibility? Labour Economics, 19(4): 527-540.

SCHÜNDELN, M. 2007. Are Immigrants More Mobile Than Natives? Evidence from Germany. IZA DP, No. 3226. Institute for the Study of Labour.

WORLD BANK. 2009. World Development Report 2009: Reshaping the Economic Geography. Washington, DC: The World Bank.

WOZNIAK, A. 2010. Are College Graduates More Responsive to Distant Labour Market Opportunities? Journal of Human Resources, 45(4):944-970.

Peter Huber: peter.huber@wifo.ac.at 